\title{
Mode of Inhibition of Chitin Synthesis by Diflubenzuron in the Cabbage Armyworm, Mamestra brassicae L.
}

\author{
Takashi Mitsui, Chieko Nobusawa and Jun-ichi Fukami \\ The Institute of Physical and Chemical Research, \\ Hirosawa, Wako 351, Japan
}

(Received July 1, 1983)

\begin{abstract}
No morphological difference was found in the epithelial cells of midgut between the normal and the diflubenzuron-treated last instar larvae of the cabbage armyworm, Mamestra brassicae L. Diflubenzuron and polyoxin D strongly inhibited chitin synthesis in the peritrophic membranes of the midgut when glucosamine or $N$-acetylglucosamine was applied, as a precursor of chitin, either inside or outside the midgut. When UDP- $N$-acetylglucosamine was injected into the midgut with polyoxin $D$, chitin synthesis was blocked, but not with diflubenzuron. The results lead to the following speculation: UDP- $N$-acetylglucosamine would be formed from glucosamine or $N$-acetylglucosamine in the epithelial cells and then move to the outer face of the biomembranes of the cells to form chitin. Diflubenzuron may act as an inhibitor of the transport system of UDP- $N$-acetylglucosamine across biomembranes, since an accumulation of UDP- $N$-acetylglucosamine is known in insects treated with diflubenzuron. $\mathrm{Na}^{+}-\mathrm{K}^{+}$ATPase and $\mathrm{Ca}^{2+}-\mathrm{Mg}^{2+}$ ATPase were not affected by the insecticide.
\end{abstract}

\section{INTRODUCTION}

The insecticide, diflubenzuron (Dimilin, TH60-40), is well known as an inhibitor of insect chitin synthesis but the mode of action of the compound remains unknown. As the final precursor of chitin synthesis, UDP- $N$ acetylglucosamine, was found to accumulate in insects treated with diflubenzuron. ${ }^{1-7)}$ Thus, it has been concluded that the compound blocks the terminal polymerization step in the chitin synthesis pathway. ${ }^{4,5}{ }^{5}$ ) The insecticidal activity of diflubenzuron was thought to be due to direct chitin synthetase inhibition. However, it is of particular interest that the insecticide does not inhibit the enzyme, whereas polyoxin $\mathrm{D}$ does. ${ }^{7-12)}$ At present, two hypotheses are proposed for the mode of inhibition of the insecticide. ${ }^{8,12,13)}$ The first one is that the insecticide interferes with the proteolytic activation of the enzyme zymogen $^{13)}$ and the second is that it disrupts a critical spatical arrangement of the enzyme complex or interferes with some delicate regulatory mechanism. ${ }^{8,12)}$ In this paper, we examined the effect of diflubenzuron on chitin synthesis using the midgut epithelial cells as a target and proposed another hypothesis that diflubenzuron affects the transport of UDP- $N$-acetylglucosamine across the biomembranes.

\section{MATERIALS AND METHODS}

\section{Experimental Animals}

Cabbage armyworm larvae, Mamestra brassicae L., were reared under sterile condition ${ }^{14}$ ) at $25^{\circ} \mathrm{C}$ under a long day $(18 \mathrm{~L}: 6 \mathrm{D})$ photoperiod regimen. Newly molted final instar (6th instar) larvae were used for the morphological observation of midgut and ATPase assay. The head capsule slipped penultimate instar larvae were collected under sterile condition into an individual plastic container with a sterile filter paper on the bottom. The newly molted final instar larvae in the containers were supplied to the midgut culture experiments within $3 \mathrm{hr}$ after molt. As usual the containers were kept at $20^{\circ} \mathrm{C}$ for about $12 \mathrm{hr}$ 
and moved to $25^{\circ} \mathrm{C}$ to allow them to molt simultaneously.

\section{Chemicals}

Diflubenzuron, 1-(4-chlorophenyl)-3-(2,6-difluorobenzoyl) urea, was supplied by Nissan Chemical Co., Ltd., Tokyo. The compound in dimethyl sulfoxide was used for all the experiments. Polyoxin D was provided by Kaken Chemical Co., Ltd., Tokyo. D- $\left[1-{ }^{14} C\right]$-glucosamine hydrochloride $\left({ }^{14} \mathrm{C}\right.$-GA, $\left.60.8 \mathrm{mCi} / \mathrm{mmol}\right)$ and uridine diphospho- $N$-acetyl-D-[U- $\left.{ }^{14} C\right]-$ glucosamine, ammonium salt $\left({ }^{14} \mathrm{C}\right.$-UDP-AGA, $275 \mathrm{mCi} / \mathrm{mmol}$ ) were purchased from The Radiochemical Centre, Amersham, England. Acetyl-D- $\left[1-{ }^{14} C\right]$-glucosamine $\left({ }^{14} \mathrm{C}\right.$-AGA, 58.18 $\mathrm{mCi} / \mathrm{mmol}$ ) and adenosine $5^{\prime}$-triphosphate, tetra(triethylammonium)salt, $\left[\gamma-{ }^{32} P\right]\left({ }^{32} P\right.$-ATP) were purchased from New England Nuclear. These compounds were dissolved in distilled water. This stock solution was then added to the medium to give the desired concentration. Other chemicals were all reagent grade.

\section{Histological Procedures}

Newly molted final instar larvae were fed on the artificial diet containing $10 \mathrm{ppm}$ diflubenzuron (the concentration completely prevented pupation) and the normal diet as control. Midguts were dissected out from the treated and the normal animals at every $24 \mathrm{hr}$ after feeding, fixed in Bouin's, sectioned at $7 \mu \mathrm{m}$ and stained with haematoxylin-eosin. Observation was made at $400 \times$ magnification with a Vanox, Olympus phase contrast microscope.

\section{Midgut Culture Procedures}

For culture in vitro, the procedures were the same as previously reported. ${ }^{15,16)}$ The final instar larvae from the individual containers as described above were surface-sterilized and the midguts were taken out. The precursors of chitin, GA, AGA and UDP-AGA, and the test compounds including the inhibitors of chitin synthesis and ATPase were applied to the midguts following the 3 application methods as shown in Fig. 1.

\subsection{Outside application}

After posterior end of the midgut was ligated by cotton thread, Grace's medium was injected into the midgut and then, the other

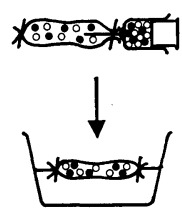

(a)

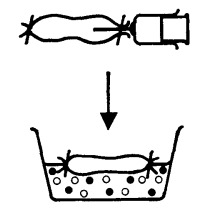

(b)

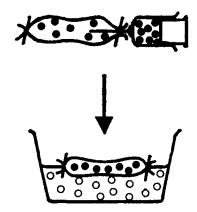

(c)
Fig. 1 Application methods of the inhibitors and the precursors to the ligated midguts.

(a): inside, (b): outside, (c): inside-outside. $\bigcirc$ : ${ }^{14} C$-precursor, $\bullet$ : inhibitor, medium: Grace's medium.

end was ligated as well. The ligated midguts were cultured in the Grace's medium in the presence of the inhibitors and the precursors for 16 to $24 \mathrm{hr}$.

\subsection{Inside application}

A given amount of the individual inhibitors and precursors was injected into the midgut ligated at the posterior end and the other end was also ligated after injection. The ligated midgut was cultured in the plain Grace's medium.

\subsection{Inside-outside application}

After the inhibitors were injected into the ligated midgut, it was cultured in the Grace's medium in the presence of the precursor. All procedures were conducted under sterile condition.

\section{Analysis of Chitin Synthesis}

After in vitro culture for 16-24 hr, 6 midguts were homogenized in $10 \mathrm{ml} \mathrm{5 \%}$ trichloroacetic acid with a glass homogenizer and then centrifuged. The pellets were digested in $2 \mathrm{ml} \mathrm{30 \%}$ $\mathrm{KOH}$ at $100^{\circ} \mathrm{C}$ for $2 \mathrm{hr}$ and then diluted with $10 \mathrm{ml}$ distilled water. The indigested material was collected on a glass-fiber filter (GC 50) and washed twice with $10 \mathrm{ml}$ distilled water, twice with $10 \mathrm{ml}$ acetone and twice again with $10 \mathrm{ml}$ distilled water. The radioactivity incorporated into chitin was determined by combustion of the indigested material along with the filter using Sample Oxidizer (Packard Tri-Carb B306) followed by scintillation counting (Packard Tri-Curb $460 \mathrm{CD}$ ). When the ligated midgut in which the inhibitor was injected was cultured in the presence of the precursors (the inside-outside application), both ends were cut off from the ligated midgut before analysis. 


\section{ATPase Activity}

The method of Anstee and Bell ${ }^{17}$ was modified for the assay of $\mathrm{Na}^{+}-\mathrm{K}^{+}$ATPase activity. Midgut, about $2 \mathrm{~g}$, was dissected out from 50 newly molted final instar larvae and homogenized in $20 \mathrm{ml}$ of ice-cold buffer A containing of $250 \mathrm{~mm}$ mannitol, $5 \mathrm{~mm}$ EDTA, $0.1 \%$ sodium deoxycholate in $30 \mathrm{~mm}$ histidine$\mathrm{HCl}, \mathrm{pH}$ 7.2. The resulting homogenate was then treated with sodium iodide as described by Nakao et al. ${ }^{18)}$ and centrifuged at $25,000 \mathrm{~g}$ for $30 \mathrm{~min}$ at $0^{\circ} \mathrm{C}$. The supernatant was centrifuged at $105,000 \mathrm{~g}$ for $60 \mathrm{~min}$. The resulting pellets were resuspended in $5 \mathrm{ml}$ buffer B (4 mu $\mathrm{MgCl}_{2}, 100 \mathrm{~mm} \mathrm{NaCl}, 20 \mathrm{~mm}$ $\mathrm{KCl}, 0.1 \mathrm{~mm}$ EDTA in $10 \mathrm{~mm}$ Tris- $\mathrm{HCl}, \mathrm{pH} 7.5$ ) after washing with $10 \mathrm{~mm}$ Tris- $\mathrm{HCl}$ buffer $(\mathrm{pH}$ 7.5) containing of $1 \mathrm{~mm}$ EDTA and used as the enzyme. The inhibitor in $50 \mu 1$ solvent was added to the assay mixture containing a $100 \mu \mathrm{l}$ aliquot of enzyme source (60-100 $\mu \mathrm{g}$ protein) and $0.85 \mathrm{ml}$ of the buffer $\mathrm{B}$. The reaction was initiated by the addition of $100 \mu 1{ }^{32} \mathrm{P}-\mathrm{ATP}$ (final concentration $0.25 \mathrm{~mm}$ ). After incubation at $30^{\circ} \mathrm{C}$ for $20 \mathrm{~min}$, the liberated ${ }^{32} \mathrm{P}$ was measured following the method of Yamaguchi et al. ${ }^{19)}$ For the $\mathrm{Na}^{+}-\mathrm{K}^{+}$ATPase activity of midguts excised from the insects treated with diflubenzuron, newly molted final instar larvae were fed on the artificial diet containing $10 \mathrm{ppm}$ diflubenzuron and the normal diet as a control, and sacrificed $24 \mathrm{hr}$ after feeding was started.

$\mathrm{Ca}^{2+}$ ATPase activity was measured following the method of Yamaguchi et al. ${ }^{19)}$ Preparation of enzyme source was the same as the above except for the sodium iodide treatment. The resulting pellets were suspended in $5 \mathrm{ml}$ buffer $\mathrm{C}$ which consisted of $5 \mathrm{~mm} \mathrm{MgCl}_{2}, 100 \mathrm{~mm}$ $\mathrm{KCl}, 1 \mathrm{~mm}$ EGTA in $10 \mathrm{~mm}$ Tris- $\mathrm{HCl}$ ( $\mathrm{pH} 7.5)$. A $100 \mu \mathrm{l}$ aliquot of enzyme source (about $60 \mu \mathrm{g}$ protein) was incubated with the inhibitor in $0.85 \mathrm{ml}$ buffer $\mathrm{C}$. The reaction was started by addition of ${ }^{32} \mathrm{P}-\mathrm{ATP}$ (final concentration 0.5 $\mathrm{mm}$ ) and the incubation was carried out at $30^{\circ} \mathrm{C}$ for $10 \mathrm{~min}$ for $\mathrm{Mg}^{2+}$ ATPase activity. For $\mathrm{Ca}^{2+}-\mathrm{Mg}^{2+}$ ATPase activity, $0.47 \mathrm{~mm} \mathrm{CaCl}_{2}$ was added to the reaction mixture. The liberated ${ }^{32} \mathrm{P}$ was measured as above.

\section{RESULTS}

\section{Histological Observation of Midgut}

The midgut was made up of two types of epithelial cells, i.e., columnar and goblet cells, a basement membrane and muscle in newly molted larvae as shown in Fig. 2A. The epithelial cells bear short microvilli inside the midgut and are covered by a thin sheath, that is, peritrophic membrane, which has the same components as the inner layers of the cuticle;

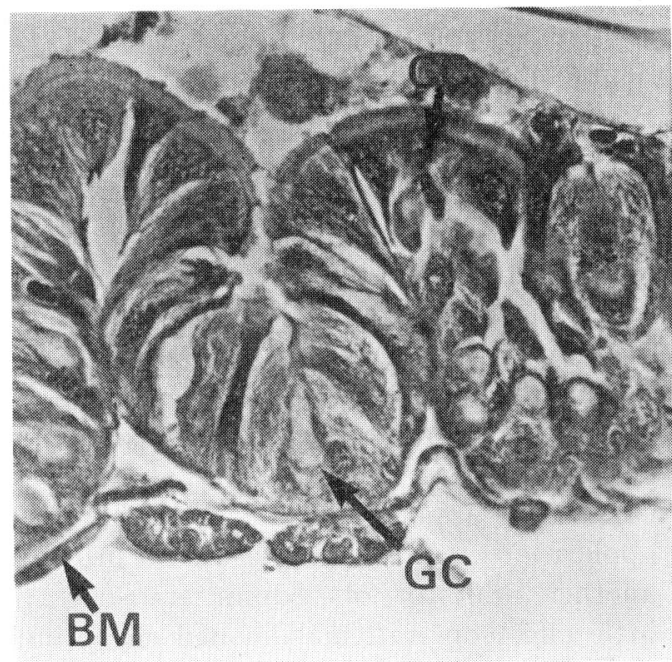

A

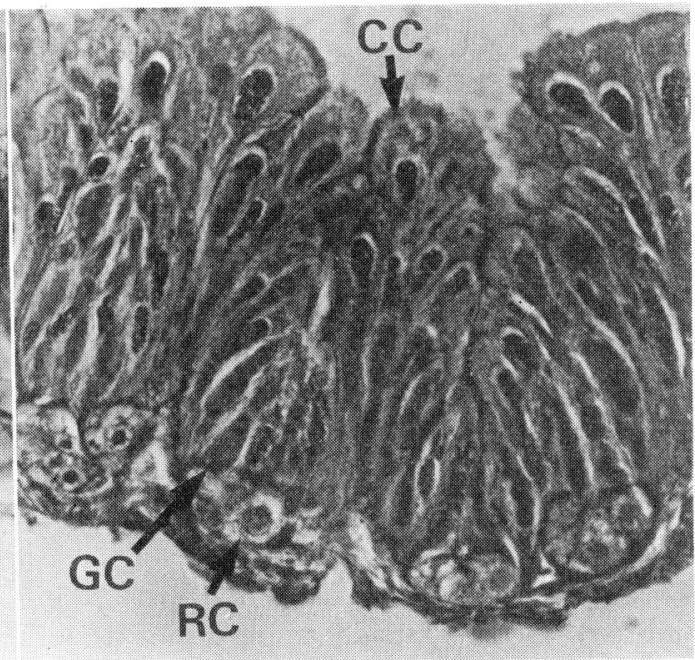

B

Fig. 2 The section of the midgut of Mamestra last instar larvae.

$\mathrm{CC}$ : columnar cells, GC: goblet cells, RC: regenerative cells, BM: basement membrane, A: newly molted last instar larvae, B: wandering larvae (5 days after molt). 
Table 1 Effect of inhibitors on chitin synthesis in Mamestra midguts in vitro by the outside application.

\begin{tabular}{llcrr}
\hline $\begin{array}{c}\text { Precursor } \\
(0.1 \mu \mathrm{Ci} / \mathrm{ml})\end{array}$ & \multicolumn{1}{c}{ Inhibitor } & $\begin{array}{c}\text { Concentration } \\
(\mu \mathrm{g} / \mathrm{ml})\end{array}$ & $\begin{array}{c}{ }^{14} \mathrm{C} \text { incorporated } \\
(\mathrm{dpm})\end{array}$ & Rate \\
\hline${ }^{14} \mathrm{C}$-AGA & Control & & 14,681 & 100 \\
& Diflubenzuron & 1 & 1,979 & 13.9 \\
& Polyoxin D & 5 & 2,578 & 17.6 \\
& & 1 & 10,833 & 73.8 \\
& Ouabain & 50 & $14,82.7$ & 101.0 \\
& & 5 & 15,268 & 104.0 \\
& Heptachlor epoxide & 50 & 14,946 & 109.6 \\
& Ethacrynic acid & 50 & 16,090 & 89.4 \\
\hline${ }^{14} C$-UDP-AGA & Captan & 50 & 13,120 & 100 \\
& Control & & 705 & 29.2 \\
\hline
\end{tabular}

Table 2 Effect of inhibitors on chitin synthesis in the peritrophic membranes by the inside-outside application.

\begin{tabular}{lccc}
\hline Inhibitor & $\begin{array}{c}\text { Concentration } \\
(\mu \mathrm{g} / \mathrm{ml})\end{array}$ & $\begin{array}{c}{ }^{14} \mathrm{C} \text { incorporated } \\
(\mathrm{dpm})\end{array}$ & Rate \\
\hline Control & & 3,264 & 100 \\
Diflubenzuron & 1 & 596 & 18.3 \\
Polyoxin D & 5 & 875 & 26.8 \\
Furosemide & 50 & 3,091 & 94.7 \\
Ouabain & 50 & 2,827 & 86.6
\end{tabular}

The ligated midguts, in which the inhibitors were injected, were cultured in the Grace's medium in the presence of $0.1 \mu \mathrm{Ci} / \mathrm{ml}{ }^{14} \mathrm{C}$-AGA.

a basis of chitin with protein incorporated in it. $^{20)}$ At the wandering stage, 5 days after final molt, the small basal cells, regenerative cells, appeared on the basement membrane (Fig. 2B). At pupation, the epithelial cells degenerated and the regenerative cells grew to replace them. So, the larval midgut was completely renewed to the pupal midgut. When the larvae were fed on the diet containing $10 \mathrm{ppm}$ diflubenzuron, pupation was completely prevented but no morphological difference was observed in the epithelial cells between the treated and the normal insects.

\section{Inhibition of Chitin Synthesis}

When the midguts were treated with the inhibitors by the outside application using ${ }^{14} \mathrm{C}$-AGA as a precursor, diflubenzuron and polyoxin $\mathrm{D}$ strongly inhibited chitin synthesis in peritrophic membranes as shown in Table 1. Captan showed only $10 \%$ inhibition at high concentration of $50 \mu \mathrm{g} / \mathrm{ml}$. Other compounds, ouabain, a typical inhibitor of $\mathrm{Na}^{+}-\mathrm{K}^{+}$ATPase, heptachlor epoxide, an inhibitor of $\mathrm{Ca}^{2+}-\mathrm{Mg}^{2+}$ ATPase, and ethacrynic acid, an inhibitor of sodium transport, had no effect on chitin synthesis in vitro. When ${ }^{14} C$-UDP-AGA was used as a precursor in the outside application, incorporated radio activity was only $705 \mathrm{dpm}$ even in the control. It may be due to poor penetration of UDP-AGA into the cells from outside (blood circulation).

Diflubenzuron and polyoxin D also inhibited chitin synthesis when the inhibitor and precursor were applied following the inside-outside application method (Table 2). Furosemide, another inhibitor of sodium transport, had little effect on it. Ouabain had slight inhibition of it when injected into the ligated midguts, whereas no inhibition was observed by the outside application method as above. In this method, the both ligated ends were cut off 
Table 3 Effect of diflubenzuron and polyoxin D on chitin synthesis in the peritrophic membranes in vitro by the inside application.

\begin{tabular}{|c|c|c|c|c|}
\hline Precursor & Inhibitor & $\begin{array}{l}\text { Concentration } \\
(\mu \mathrm{g} / \mathrm{ml})\end{array}$ & $\begin{array}{c}{ }^{14} \mathrm{C} \text { incorporated } \\
(\mathrm{dpm})\end{array}$ & Rate \\
\hline${ }^{14} C$-UDP-AGA & Control & & 21,942 & 100 \\
\hline \multirow[t]{6}{*}{$0.02 \mu \mathrm{Ci} /$ animal } & Diflubenzuron & 0.25 & 23,785 & 108.4 \\
\hline & & 1.0 & 19,726 & 89.9 \\
\hline & & 2.5 & 21,986 & 100.2 \\
\hline & Polyoxin D & 1.0 & 7,306 & 33.3 \\
\hline & & 4.0 & 7,329 & 33.4 \\
\hline & & 5.0 & 5,771 & 26.3 \\
\hline${ }^{14} C-\mathrm{AGA}$ & Control & & 15,986 & 100 \\
\hline $0.04 \mu \mathrm{Ci}$ /animal & Diflubenzuron & 1.0 & 3,534 & 22.1 \\
\hline${ }^{14} \mathrm{C}-\mathrm{GA}$ & Control & & 1,978 & 100 \\
\hline \multirow[t]{3}{*}{$0.1 \mu \mathrm{Ci}$ /animal } & Diflubenzuron & 0.25 & 438 & 22.1 \\
\hline & & 1.0 & 646 & 32.7 \\
\hline & & 2.5 & 312 & 15.8 \\
\hline
\end{tabular}

after incubation and the remaining midguts (about 1/3 of total midguts) were supplied for chitin analysis. So, the incorporated radio activity in the control was about $1 / 3$ as much as in the control of the outside application (Table 1).

When diflubenzuron and polyoxin $\mathrm{D}$ were injected into the ligated midguts with ${ }^{14} \mathrm{C}$ UDP-AGA as a precursor, diflubenzuron did not inhibit chitin synthesis at all at the concentration of $0.25-2.5 \mu \mathrm{g} / \mathrm{ml}$, whereas polyoxin $\mathrm{D}$ did it (Table 3 ). On the other hand, when ${ }^{14} \mathrm{C}$-GA or ${ }^{14} \mathrm{C}$-AGA was used as a precursor in the inside application, diflubenzuron showed a strong inhibition of chitin synthesis as done by other application methods.
3. Effect of Diflubenzuron on ATPase Activity

From above experiment, diflubenzuron was considered to bring about the change of midgut permeability to UDP-AGA across the biomembranes of the epithelial cells. Then, the ATPase, an active ion pump, was extracted from the midgut and the enzyme activity was assayed as described in the section for Methods. As shown in Table $4, \mathrm{Na}^{+}-\mathrm{K}^{+}$ATPase from the midgut was not so sensitive to ouabain, that is, about $30 \%$ inhibition at $8.5 \times 10^{-5} \mathrm{M}$. Ethacrinic acid exerted a slight inhibition but the other compounds, diflubenzuron and oligomycin, gave no inhibition. The midguts were taken out from the larvae fed on the diet containing $10 \mathrm{ppm}$ diflubenzuron for $24 \mathrm{hr}$ after molting. Then the enzyme activity was as-

Table 4 Effect of inhibitors on $\mathrm{Na}^{+}-\mathrm{K}^{+}$ATPase activity.

\begin{tabular}{lccc}
\hline Inhibitor & $\begin{array}{c}\text { Concentration } \\
(\mathrm{M})\end{array}$ & $\begin{array}{c}\text { Activity } \\
(\mathrm{nmol} / \mathrm{mg} \text { protein })\end{array}$ & Rate \\
\hline In vitro & & 140 & 100 \\
Control & $3.2 \times 10^{-4}$ & 158 & 112.9 \\
Diflubenzuron & $8.5 \times 10^{-5}$ & 103 & 73.6 \\
Ouabain & $3.3 \times 10^{-4}$ & 130 & 92.9 \\
Ethacrinic acid & $6.2 \times 10^{-5}$ & 154 & 110 \\
Oligomycin & & & 100 \\
In vivo & & 136 & 96 \\
Control & & 131 & \\
Diflubenzuron & & & \\
\hline
\end{tabular}


Table 5 Effects of diflubenzuron and heptachlor epoxide on $\mathrm{Mg}^{2+} \mathrm{ATPase}$ and $\mathrm{Ca}^{2+}-\mathrm{Mg}^{2+}$ ATPase activity.

\begin{tabular}{|c|c|c|c|c|c|}
\hline \multirow{2}{*}{ Inhibitor } & \multirow{2}{*}{$\begin{array}{l}\text { Concentration } \\
\text { (M) }\end{array}$} & \multicolumn{2}{|c|}{$\mathrm{Mg}^{2+}$ ATPase } & \multicolumn{2}{|c|}{$\mathrm{Ca}^{2+}-\mathrm{Mg}^{2+}$ ATPase } \\
\hline & & $\begin{array}{c}\mathrm{nmol} / \mathrm{mg} \\
\text { protein } / \mathrm{min}\end{array}$ & $\begin{array}{c}\text { Inhibition } \\
(\%)\end{array}$ & $\begin{array}{c}\mathrm{nmol} / \mathrm{mg} \\
\text { protein/min }\end{array}$ & $\begin{array}{c}\text { Inhibition } \\
(\%)\end{array}$ \\
\hline Control & - & 6.9 & - & 32.2 & - \\
\hline \multirow[t]{3}{*}{ Diflubenzuron } & $8.0 \times 10^{-6}$ & 6.2 & 10.1 & 34.9 & 0 \\
\hline & $8.0 \times 10^{-5}$ & 2.8 & 59.0 & 37.1 & 0 \\
\hline & $3.2 \times 10^{-4}$ & 4.3 & 37.9 & 35.4 & 0 \\
\hline $\begin{array}{l}\text { Heptachlor } \\
\text { epoxide }\end{array}$ & $2.5 \times 10^{-4}$ & 6.8 & 1.5 & 25.6 & 20.5 \\
\hline
\end{tabular}

sayed. There was no difference in activity between the treated and the normal insects.

Diflubenzuron inhibited, as shown in Table 5, $\mathrm{Mg}^{2+}$ ATPase at high concentrations, but the effect of inhibition was completely recovered by an addition of $\mathrm{Ca}$ ion to the reaction medium. As a result, diflubenzuron had no effect on $\mathrm{Ca}^{2+}-\mathrm{Mg}^{2+}$ ATPase at all, whereas heptachlor epoxide slightly inhibited the enzyme.

\section{DISCUSSION}

The midgut culture system is ideal for the study on the mechanism of chitin synthesis. The epithelial cells are exposed to the midgut cavity as microvilli whereas the epidermal cells adhere to the overlying cuticle. Therefore, in the epithelial cells the inhibitors and the precursors can be directly applied to the outer face of the biomembranes. Diflubenzuron and polyoxin D strongly inhibited chitin synthesis in the peritrophic membranes when applied from either inside or outside of the midguts using GA or AGA as a precursor. On the other hand, when UDP-AGA was directly applied to the surface of the microvilli, diflubenzuron did not block chitin synthesis, whereas polyoxin $\mathrm{D}$ did. These results may indicate that diflubenzuron blocks the formation of UDP-AGA from AGA which is mediated by UDP-AGA pyrophosphorylase. However, this is contradictory to the findings on the accumulation of UDP-AGA in the insects treated with diflubenzuron.

When GA or AGA is applied to the midgut, it should be incorporated into the cells to form UDP-AGA and then, the resulting UDP-AGA should be pumped out to the outer face of the biomembranes of the microvilli (Fig. 3A, B). On the other hand, UDP-AGA applied to the surface of the microvilli need not permeate into the cells but it can be directly used in situ for chitin synthesis by chitin synthetase which will be on the outer face of the biomembranes of the microvilli (Fig. 3C). However, it is unknown, so far, where in the membranes the chitin synthetase is located, although it is

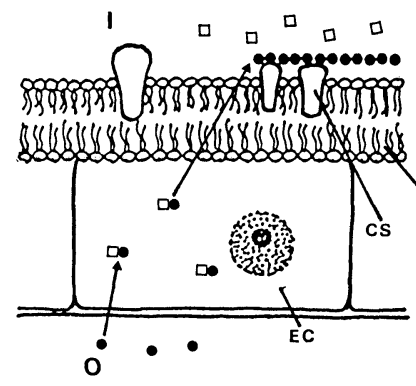

A

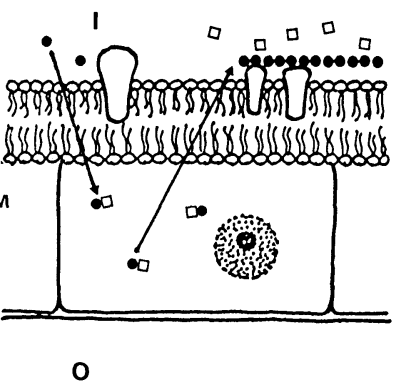

B

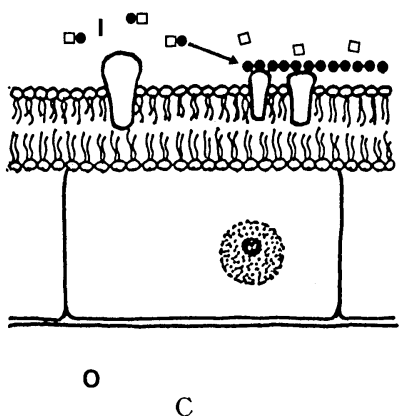

C

Fig. 3 Summary of the roles of diflubenzuron in the epithelial cells.

๑: AGA, $\square$ : UDP, CS: chitin synthetase, I: inside the midgut, O: outside the midgut, EC: epithelial cell, M: biomembrane. 
certain that the enzyme is located on the biomembranes.

Concerning the mode of action of diflubenzuron, several hypotheses are proposed. Horst $^{21)}$ reported that diflubenzuron inhibited chitin synthetase in vitro from brine shrimp larvae. Insect integumental chitin synthetase, however, is reported to be insensitive to diflubenzuron in Trichoplusia $n i$ and Hyalophora cecropia ${ }^{12)}$ and the result agrees well with the earlier findings on insect gut or whole body enzyme preparations in Tribolium castaneum, $^{8)}$ Stomoxys calcitrans ${ }^{9,10)}$ and Mamestra brassicae. ${ }^{7111}$ It has also been proposed that diflubenzuron prevents chitin synthesis by interfering with the proteolytic activation of the chitin synthetase zymogen. ${ }^{13)}$ Another possible speculation is proposed by Cohen and Casida $^{8)}$ that diflubenzuron acts either as chitin synthetase inhibitor via active metabolites formed in the integument or as blocking agent by direct binding to non-chitin synthetase sites important in chitin polymerization and fibrillogenesis.

The results of the present work seem to suggest another mechanism that diflubenzuron may disrupt transport systems of the final precursor, UDP-AGA which is enzymatically synthesized from GA or AGA in the epithelial cells, through biomembranes, although it is obscure whether or not chitin synthesis process in the peritrophic membranes is the same as the integuments. Then, the effect of the insecticide on ATPase activity was checked. However, the enzymes were not affected by diflubenzuron. Other possible transport system will be further studied in future.

IBP and edifenphos, organophosphorus fungicides, were found to inhibit biosynthesis of phosphatidylcholine, a main component of biomembranes. ${ }^{22,23)}$ These results propose another possibility that diflubenzuron might affect the membrane formation and, as a result may disrupt the function of the membranes. Diflubenzuron stimulated chitin synthesis in a fungus, Pyricularia oryzae, using protoplasts of the fungus. ${ }^{24)}$ Regarding chitin synthesis, stimulation in fungus but inhibition of it in insect still remains unsolved causing much perplexity, even if diflubenzuron may affect biomembranes.
Captan is reported to inhibit chitin synthesis in peritrophic membranes in Calliphora erythrocephala ${ }^{25)}$ and to suppress insect cuticle formation. ${ }^{26)}$ The compound also inhibits insect chitin synthetase in $T$. castaneum, ${ }^{8)} T$. $n i$ and $H$. cecropia. ${ }^{12}$ In this experiment, however, it was shown that chitin synthesis was inhibited only to a lesser degree. Ouabain was a weak inhibitor when applied inside but not when applied outside. Probably the midgut is not permeable to the compound through blood circulation.

\section{ACKNOWLEDGEMENTS}

We thank Dr. I. Yamaguchi and Dr. K. Yoneyama, The Institute of Physical and Chemical Research, for their critical discussion of the experiments. We also thank Dr. K. Wakabayashi, Mitsubishi Kasei Co., for his kindness in reading the manuscript and for his fruitful discussion.

\section{REFERENCES}

1) L. C. Post, B. J. de Jong \& W. R. Vincent: Pestic. Biochem. Physiol. 4, 473 (1974)

2) D. H. Deul, B. J. de Jong \& J. A. M. Kortenbach: Pestic. Biochem. Physiol. 8, 98 (1978)

3) N. P. Hajjar \& J. E. Casida: Science 200, 1499 (1978)

4) N. P. Hajjar \& J. E. Casida: Pestic. Biochem. Physiol. 11, 33 (1979)

5) W. H. von Eck: Insect Biochem. 9, 295 (1979)

6) T. Mitsui, C. Nobusawa, J. Fukami, J. Colins \& L. M. Riddiford: J. Pesticide Sci. 5, 335 (1980)

7) T. Mitsui, J. Fukami \& L. M. Riddiford: "Regulation of Insect Development and Behaviour," ed. by F. Sehnal, A. Zabza, J. J. Menn \& B. Cymborowsky, Scientific Papers of the Institute of Organic and Physical Chemistry of Wroclaw Technical University, No. 22, p. 1131 (1981)

8) E. Cohen \& J. E. Casida: Pestic. Biochem. Physiol. 13, 129 (1980)

9) R. T. Mayer, A. C. Chen \& J. R. DeLoach: Insect Biochem. 10, 549 (1980)

10) R. T. Mayer, A. C. Chen \& J. R DeLoach: Experientia 37, 337 (1981)

11) T. Mitsui, C. Nobusawa \& J. Fukami: J. Pesticide Sci. 6, 155 (1981)

12) E. Cohen \& J. E. Casida: Pestic. Biochem. Physiol. 17, 301 (1982)

13) T. Leighton \& E. Marks: Science 213, 905 (1981)

14) M. Hattori \& S. Atsusawa: Jpn. J. Appl. Entomol. Zool. 24, 36 (1980)

15) T. Mitsui \& L. M. Riddiford: Dev. Biol. 54, $172(1976)$ 
16) T. Mitsui \& L. M. Riddiford: Dev. Biol. 62 , 193 (1978)

17) J. H. Anstee \& M. Bell: J. Insect Physiol. 21, 1779 (1975)

18) T. Nakao, Y. Tashima, K. Nagano \& M. Nakao: Biochem. Biophys. Res. Commun. 19, 755 (1965)

19) I. Yamaguchi, F. Matsumura \& A. A. Kadous: Biochem. Pharmacol. 29, 1815 (1980)

20) V. B. Wigglesworth: "The Principles of Insect Physiology," Methuen, London, p. 427, 1965

21) M. N. Horst: J. Biol. Chem. 256, 1412 (1981)

22) O. Kodama, K. Yamashita \& T. Akatsuka: Agric. Biol. Chem. 43, 1719 (1979)

23) O. Kodama, K. Yamashita \& T. Akatsuka: Agric. Biol. Chem. 44, 1015 (1980)

24) K. Yoneyama: personal communication

25) B. Becker: J. Insect Physiol. 24, 699 (1978)

26) E. P. Marks \& B. A. Sowa: "The Insect Integument," ed. by H. R. Hepburn, Elsevier Scientific Publ. Co., Amsterdam-Oxford-New York, p. 339,1976
要 約

\section{ヨトウガにおける diflubenzuron のキチン合成 阻害機構}

満井 喬, 信沢智恵子, 樑見順一

ヨトウガ (Mamestra brassicae) 終歯令幼虫を供試して, 中腸の上皮細胞に及ぼす diflubenzuron の影響を組織学 的に観察した結果, 細胞にはまったく影響がみられなか った. ${ }^{14} \mathrm{C}$ 標識したグルコサミンあるいはアセチルグル コサミンを前駆物質として, in vitro で中腸に投与した 場合, 中腸内に注入しても, 培養液中に添加しても, 囲 食膜のキチン質にとり込まれた。 diflubenzuron, polyoxin D はこのとり込みを強く阻害した。. ${ }^{14} \mathrm{C}$ 標識した UDP-N-アセチルグルコサミンを前駆物質として, diflubenzuron または polyoxin D とともに中腸内に注入 すると, polyoxin D はキチン合成を阻害するが, diflubenzuron では阻害がみられなかった。このことから， diflubenzuron はUDP-N-アセチルグルコサミンの生体 膜透過に関与しているものと推察された. しかし, $\mathrm{Na}^{+}$ $\mathrm{K}^{+}$ATPase, $\mathrm{Ca}^{2+}-\mathrm{Mg}^{2+}$ ATPase など生体膜のポンプに 対してはまったく影響がみられなかった。 